\title{
The Affinity to the People of the Socialist Ideology with Chinese Characteristics in the New Era by Xi Jinping
}

\author{
Chen $\mathrm{Yu}^{1, \mathrm{a}}$, Wang Jiajia ${ }^{1, b}$ \\ ${ }^{1}$ Taizhou Polytechnic College, Jiangsu Taizhou, China, 225300 \\ axiaoyueryuchen@163.com bwangjiajia_99@163.com
}

Keywords: New era, The socialist, Affinity to the people

\begin{abstract}
Xi Jinping's socialist thought with Chinese characteristics in the new era is the most vivid Marxism in contemporary China, the most fundamental reason lies in its firm adherence to the Marxist position, views, and methods from inception to establishment. At all times, it is firmly following the basic value orientation of the people first and the highest value pursuit of the all-round development of human beings, and has been enriching and developing the affinity to the people, which fully demonstrates the most fundamental political stand of the Marxist party--the people's stand.
\end{abstract}

\section{Introduction}

Marxism is a constantly developing theory with the theoretical quality of keeping pace with the times. To judge whether a new ideological system and theoretical achievements are Marxism or not, the most fundamental thing is to see whether or not it always adheres to the position, viewpoint and methods of Marxism. The most important is to see if it has a Marxist political stand -- always standing on the stand of the masses and earnestly seeking the interests of the people. Xi Jinping's socialist ideology with Chinese characteristics in the new era has always taken well realized, safeguard and developed the fundamental interests of the overwhelming majority of the people as the fundamental purpose of development, and pointed out clearly that we must adhere to the people-centered thinking of development, constantly promote the all-round development of the people, and make all the people prosperous together. It embodies the fundamental value orientation of the people first and the highest value pursuit of the all-round development of the people at all times, scientific guides the Chinese Communists for the happiness of the Chinese people, has a strong people's nature.

At the same time, "insist on the people as the center," insist on the people as the master, "insist on the development of the protection and improvement of people's livelihood," "insist on the harmonious coexistence between people and nature", "insist on promoting the building of a community of human destiny," and so on , the specific requirements and others are very clear with the people's interests, and closely related to each other which are taken together as the 14 basic strategies for the full and accurate implementation of Xi Jinping's thought of socialism with Chinese characteristics in the new era. It can be said that, 14 basic strategies are closely related to the interests of the people, these are for the greatest number of the people and run through the Marxist masses' views, some of which are explicit and some are hidden. It clearly shows the ruling feelings of "people's livelihood logic" and "people first" of the Party Central Committee, with Comrade Xi Jinping as the core, and fully demonstrates the three dimensions of the affinity to the people. It has became the most vivid Marxism in contemporary China.

\section{Practice dimension: to strive for the people's yearning for a better life}

The aims and purposes of a political party embody its fundamental value orientation. The Communist Party of China's first heart is always to work for the well-being of the people as their own responsibility. From "emancipation for the sake of the labouring masses" to "serving the people" to "taking the people as the center". In different historical periods, different stages of development, with 
different formulations and expressions, but there is only one core intention, that is, always put the people in the highest position, strive to serve the people and to be happy for the people at all times. From the "serving the masses" hanging high in the Zaoyuan auditorium in Yan'an at that time to the "serving the people" engraved on the Xinhua door wall of Zhongnanhai today, the fundamental purpose has always been in the same vein, the political stand has always been the same. At the end of December 2012, General Secretary Xi Jinping pointed out, "We have spoken a lot of words on purpose, but in the end it is still about serving the people. Our party serves the people." More than a month ago, when he took office for the first time, he put forward the objective of the CPC Central Committee: "the people's yearning for a better life is our goal." This clearly shows that, at that time, he had a relatively clear judgment on the entry of socialism with Chinese characteristics into a new era, and his understanding of the transformation of the principal social contradictions in China in the new era was very mature. The change of the principal social contradictions was the basic basis for entering the new era. It is also the practical support of the construction of socialism with Chinese characteristics in the new era of Xi Jinping.

The proposition of "the people's yearning for a better life" marks a solid practical foundation for Xi Jinping's socialist thinking with Chinese characteristics in the new era. From which we can profoundly understand that one stands firmly in the position of the people, well realize safeguard and develop the fundamental interests of the overwhelming majority of the people is always the starting point and foothold of all the work of the party and the state. But the goal seems to be the most unusual. As the General Secretary has stressed, "the great rejuvenation of the Chinese nation can never be achieved easily. The whole party must be prepared to give more arduous work and more strenuous efforts." ${ }^{[1]}$ It is not easy to satisfy the people's yearning for a better life, because it involves the real interests, the urgent desire and the ideal of life of the masses, and it is not something that can be easily achieved, we must pay a hundred times as much hardship and effort. The most fundamental of these is to listen to the voice of the people from the bottom of their hearts, to deeply understand the sufferings of the people who are unable to do what they can, and to constantly help them to realize the beautiful vision in their hearts. In the final analysis, it is necessary to do our utmost to achieve, safeguard, and develop the fundamental interests of the overwhelming majority of the people, and to solve the major social contradictions of the new era.

\section{Theoretical dimension: the thought of China's Development in the New era with the people as the Center}

The people are the successors and beneficiaries of the achievements of development, the implementers and the participants in the practice of development. We must look among the people for a motive force for development and rely on the people to promote development. Since the 18 National Congress of the Party, the Party Central Committee with Comrade Xi Jinping as the core, has always stood on the stand of the people and constantly enriched and perfected the concept of the people first. From "people's yearning" to "people's obtaining", to "people being the center", it fully shows the immutable initial heart which is everything for the people. July 2016, at a general meeting to celebrate the 95th anniversary of the founding of the Communist Party of China, General Secretary Xi Jinping comprehensively elaborated on the concept of the people, stressing that the people should be placed in the highest position in our hearts, leading the people to create a happy life, and respecting the people's dominant position, ensure that the people are the masters of their own affairs. Serving the people is an idea that run throughout the 19th CPC National Congress's report, from the theme of the congress, "never forget the initial mind," to the characteristics of the "new era," from the new judgment of the "new contradiction," to the specific layout of the strategy, all highlight the idea of people first. There are thirteen parts of the report, each part of the report could reflect the Chinese Communist Party's idea of "building the party for the common good and government for the people." It can be said that, the development thought of people-centered put forward by the fifth Plenary session of the 18 CPC Central Committee for the first time embodies the fundamental purpose of the CPC in serving the 
people wholeheartedly and fully demonstrates the value orientation of the people as supreme. It also reflects the people's main position and internal requirements of development depends on the people, and has become the soul of Xi Jinping's socialist thought with Chinese characteristics in the new era.

At the same time, insisting on the people as the center also profoundly reflects the value pursuit of the historical materialism that the Communist Party of China has always adhered to, and has a solid and profound theoretical basis. Historical materialism is an important part of Marxist philosophy. It is the theoretical cornerstone of the Party and the theoretical basis for the Chinese Communists to understand and transform the world, it is also the world outlook and methodology for observation and analysis to solve problems. General Secretary Xi Jinping has repeatedly stressed that "it is necessary to promote the whole party to study the basic principles and methodology of historical materialism and to better understand the law of historical development, be more dynamic in advancing all kinds of work." Historical materialism has established the position of the people as the main body of history, emphasizing that the people are the fundamental force in promoting development. Tracing back history is not to stretch out feelings, but to shine on reality, take innovation theory to serve the vivid and hot practice. Insist on taking the people as the center, the most important thing is to solve the fundamental problem of who to develop and by whom to develop. In the final analysis, it is necessary to always put the interests of the people in the supreme position. Taking the solution of major practical problems as the work guide and relying closely on the strength of the overwhelming majority of the people, focusing on solving the most direct and realistic interests of the masses. This is to play a decisive role in the founding of Xi Jinping's socialist ideology with Chinese characteristics in the new era. General Secretary Xi Jinping, who made a decisive contribution, inherited and developed the Marxist viewpoint on the people and formed a complete, comprehensive view of the people, which is also the most solid theoretical support for the affinity to the people of the socialist ideology with Chinese characteristics in the new era of Xi Jinping.

\section{Development dimension: taking the free and all-round development of human being as the ultimate value goal}

The free and all-round development of human beings was the highest ideal and ultimate value goal that Marx and Engels pursued all their life. It runs through the whole Marxist thought system and every concrete Marxist theory which formed after them. It embodies the fundamental value and spirit of Marxism. Xi Jinping's socialist thought with Chinese characteristics in the new era has firmly adhered to and developed the core value pursuit of this Marxist humanism. General Secretary Xi Jinping has always been highly concerned about the free and all-round development of human beings, has always emphasized the concern for the development of the human being itself. It is one of the fundamental differences between socialism and capitalism. Socialism is the primary stage of communism. What is communism? It is the conclusion of the second part of the Manifesto of the Communist Party: "instead of the old bourgeois society where class and class antagonism exists, it will be such a union, where the free development of everyone is the condition for the free development of all human beings." ${ }^{2]}$ In November 2012, General Secretary Xi Jinping first put forward "Chinese dream" and elaborated its profound connotation. The goal is to build a socialist modernized power country. But this modernization is not only the modernization of economy, but a process of social transformation including economic, political, cultural and human modernization . It is the historical process of social progress and human's comprehensive development. Democracy is full, the rule of law is prosperous, the country is rich and the people are strong, and the free and all-round development of human beings is the proper meaning in the subject. It embodies the critique of capitalist modernization by Marxist classical writers. It is the most ideal and ultimate goal set for the realization of the free man's "consortium". It reflects the affinity to the people of the socialism thought of Chinese characteristics in the new era of Xi Jinping from higher level.

Xi Jinping's thought of Socialism with Chinese characteristics in the New era on the free and all-round development of human being also runs through the basic strategies of "adhering to the new 
concept of development," "adhering to the overall concept of national security" and "insisting on promoting the construction of a community of human destinies". Sharing is the main part of the new concept of development, it is also one of the main characteristics of the future communist society. Without sharing, it will be difficult to achieve the ultimate value goal of everyone's free and all-round development pursued by Marx. We should adhere to the overall concept of national security and take the people's security as its purpose, that is fully embodying the basic requirements of historical materialism, clearly pointing out that the fundamental purpose of safeguarding national security is to ensure the basic conditions for the survival and development of the people and to promote the free and all-round development of human beings. On the important thought of constructing the human destiny community, it contains the dreams, security and sharing of all mankind, and it is even more Marx's great achievement on the free and all-round development of human beings. All this shows that Xi Jinping's socialist thought with Chinese characteristics in the new era, which is a comprehensive echo of Marx's thoughts on the alienation and free all-round development of human beings. It is the definitive answer to the most essential and most basic question about how to adhere to and develop Marx's ideas about the free and all-round development of human beings in the new era.

Of course, these three dimensions are not isolated, they are interrelated, interdependent, indivisible, form an organic whole. The three-dimensional unity exists in Xi Jinping's socialist thought with Chinese characteristics in the new era. It embodies the affinity to the people of Xi Jinping's socialist thought with Chinese characteristics in the new era.

\section{Acknowledgement}

This article was financially supported by the Special Project of Ideological and Political Work on the Research of Philosophy and Social Science in Universities of Jiangsu(2017SJBFDY683), the Key Project of Scientific Research Fund of Taizhou Polytechnic College (TZYKYZD-17-4).

\section{References}

[1] Xi Jinping. To build a well-off society in an all-round way and win the great victory of socialism with Chinese characteristics in the new era[N], The People's Daily, October 28th 2017.

[2] Selected works of Marx and Engels vol. 1[M], People's Publishing House, pp.294, 1995. 